\title{
WHEN UNIVERSITY GOES INTO THE CITY. RESEARCH ON THE NEEDS OF THE ROMANI LIVING IN WROCŁAW
}

\author{
Joanna Panciuchin \\ University of Wrocław, University of Lower Silesia, Wrocław, Poland \\ panciuchin@gmail.com
}

The article was created as part of a doctoral project in the University of Lower Silesia that has received funding from the National Center for Research and Development under Integrated University Programs, grant agreement no. POWR.03.05.00-00-Z215/17

In 2018, the House of Peace Foundation, commissioned by the Municipality of Wrocław, invited employees of the University of Wrocław, PhD students, experts, specialists in the field of cultural and sociological studies of the city, education, and cultural animation to carry out research on cultural and educational needs of the Romani people who had been living in Wrocław since the 1990s. The Romani (also known as the Roma) are economic migrants who do not know Polish and usually have no literacy skills. Moreover, they often show no understanding of the rules that govern modern capitalist society. In Romania and other European countries, policy towards the Romani minority encountered various problems. Resettlements combined with attempts to transform traditional culture neutralize the role of language or impose lifestyle changes on the Romani did not bring the expected results. Paradoxically, actions aimed at increasing the productivity of the Roma and engaging them in the development of the country or community resulted in the intensification of such negative phenomena as social marginalization, unemployment, and poverty.

The research was triggered by the liquidation of the Romani encampment in Wrocław. Soon the case became political. The decision was justified on the grounds that the city needed to protect its positive image of a modern metropolis which offers no room for "wild" encampments and spatial conflicts among neighbors. At the same time, we need to remember that the city creates opportunities for establishing a dialogue that does not have to necessarily refer to the common good of the residents. It also leaves room for forming an opposition against national, ethnic, racial, or religious concepts. The city may thus be perceived as a laboratory and school of democracy.

Currently, the Romani of Wrocław live in a dozen locations throughout the city and are treated as individual families. Such a situation means a significant change in the structure, hierarchy, and social awareness of the community.

The article is focused on the research conducted by the university representatives. One of the researchers' tasks in the project was to create recommendations regarding social policy, social work, cultural animation, and education 
in the area of identity and integration of the Romanian Roma community in Wrocław. This means that the researchers commissioned by the Municipality of Wrocław were expected to propose solutions that could be implemented to improve the situation of the Romani community.

Keywords: Romani, Roma, city, education, ethnic minority, emancipation, democracy.

\section{КОГДА УНИВЕРСИТЕТ ВХОДИТ В ГОРОД: ИССДЕДОВАНИЕ ПОТРЕБНОСТЕЙ РОМСКОЙ ЖИЗНИ ВО ВРОЦИАВЕ}

\section{Иоанна Панчухин}

Вроцлавский университет, Университет Нижней Силезии, Вроцлав, Польша panciuchin@gmail.com

В 2018 году Фонд «Дом мира» по заказу Вроцлавского муниципалитета пригласил сотрудников Вроциавского университета (докторантов, экспертов, специалистов в области культурно-социологических исследований города, образования и культурной анимации) для проведения исследований о культурных и образовательных потребностях ромов, которые жили во Вроцлаве с 1990-х годов. Ромы являются экономическими мигрантами, которые не знают польского языка и обычно не имеют навыков грамотности. Более того, они часто не понимают правил, которые присущи современному капиталистическому обществу. В Румынии и других европейских странах политика в отношении ромского меньшинства сталкивалась с раздичными проблемами. Переселение в сочетании с попытками трансформировать традиционную культуру, нейтрализовать роль языка или навязать им изменения в образе жизни не принесло ожидаемых результатов. Как это ни парадоксально, действия, направденные на повышение продуктивности ромов и вовлечение их в развитие страны иди общины, привели к усилению таких негативных явлений, как социальная маргинализация, безработица и бедность. Исследование было инициировано ликвидацией лагеря ромов во Вроцлаве. Вскоре дело стало политическим. Решение было оправданным на том основании, что город должен был защищать свой позитивный образ современного мегаподиса, в котором нет места для «диких» иагерей и пространственных конфликтов между соседями. В то же время мы должны помнить, что город создает возможности для налаживания диалога, который не обязательно должен ссылаться на общее благо жителей. Это также оставляет место для формирования оппозиции против национальных, этнических, расовых или религиозных концепций. Таким образом, город может восприниматься как лаборатория и школа демократии. В настоящее время ромы Вроцлава живут 
в дюжине мест по всему городу и в обществе города относятся к ним как к отдельным семьям. Такая ситуация означает значительные изменения в структуре, иерархии и социальной осведомленности сообщества. Статья концентрируется на исследованиях, проводимых представителями университета. Одной из задач исследователей в проекте было создание рекомендаций, касающихся социальной политики, социальной работы, культурной анимации и образования в области самобытности и интеграции ромской общины во Вроцлаве. Это означает, что исследователи, уполномоченные муниципалитетом Вроцлава, должны были предложить решения, которые могди бы быть реализованы для улучшения положения ромской общины.

Кдючевые слова: ромы, город, образование, этническое меньшинство, эмансипация, демократия.

DOI 10.23951/2312-7899-2020-3-87-98

This article was written by a cultural studies expert who, at the invitation of external, non-university organizations (Municipality of Wrocław and the House of Peace Foundation), conducted the research as part of a project aimed at developing recommendations for the continuation of the socio-educational program addressed to the ethnic minority - a group of the Romani Roma living in Wroclaw. Qualitative methods characteristic for the humanities were used to describe and analyze the phenomena being the subject of the research - extensive, free-form interviews and field observations. The research did not serve to obtain statistical data on the economic situation of the Roma. The main goal was to analyze the changes taking place within their identity and daily practices after changing living conditions. It should be emphasized once again that this article falls within the perspective of cultural sciences. It also used elements of the theory of agonist democracy, which belongs to the area of the philosophy of politics and culture. These studies do not fall into the area of cognitive sociology, demography, or social geography. They are also much closer to theoretical pedagogy than to economics based on hard data and statistical indicators. Although the social group to which the analysis relates has been in Poland for a long time, the conditions and ways of life of its members have not yet been the subject of in-depth scientific studies in any field of research.

A community of Romani immigrants from a Romanian city Făgăraș has lived in Wrocław since the 1990s. They were forced to leave their 
country of birth because of their difficult socioeconomic situation. At this point, it is worth mentioning that, in Romania and other European countries, policy towards the Romani minority encountered various problems. Resettlements combined with attempts to transform traditional culture neutralize the role of language or impose lifestyle changes on the Romani (including attempts to change the way Romani men used to earn money) did not bring the expected results. Paradoxically, the actions aimed at increasing the productivity of the Roma and engaging them in the development of the country or community, resulted in the intensification of such negative phenomena as social marginalization, unemployment, and poverty. Political transformations in the countries of Central and Eastern Europe have further deepened these processes. Even before the transformation, in 1952, the Polish authorities issued a resolution on "the assistance for the Gypsy population in the transition to a settled way of life" [Prokop, Mach 2016, 74]. The idea was to provide the Roma with housing and jobs. However, only three or four thousand people from the Roma minority settled as a result of this action. The rest were treated as criminals and punished by milicja (the national police organization of the Polish People's Republic) for not having permanent residence, illegal gatherings, and not sending children to school. The Romani appeared to the communist authorities as "savages" who had to be forced into society. They were required to settle yet no communal or social housing was provided to them. As a result, they started to abandon their traditional nomadic lifestyle and set up their encampments in the undeveloped degraded urban areas. Their presence usually met with reluctance from the people outside the Roma community. In this way, the process of their marginalization and exclusion from the privileged white Polish society continued [Ibidem, 75]. In 1989, the centrally controlled economy was abolished, followed by the closure of state-owned factories and collective farms (kolkhozes) where the Roma used to work. As the result of the hurried transformation, social inequalities began to increase, and the minority groups (including the Romani) who had already had difficulties in adjusting to the conditions of the new system (capitalism) became even further marginalized [Szczepaniak 2015, 17]. The Romani people became victims of racist and xenophobic attacks due to their distinctive appearance (in particular, different skin color), language, or customs. This sort of a negative attitude towards the Roma minority escalated with the right-wing radicalization and the growing nationalist sentiments.

The members of the Roma community that settled in Wrocław in the allotment gardens at Paprotna and later at Kamienskiego were strongly 
affected by the negative effects of the socioeconomic changes that took place over the past three decades. The Romani people are one of the poorest groups in the entire European Union in terms of material living conditions. At the same time, they constitute one of the most numerous ethnic minorities in Europe [Kwadrans 2013, 178]. In Wrocław, they set up an informal encampment in the abandoned allotment gardens belonging to the Municipality of Wrocław. The barracks were made of waste materials and kept warm thanks to the self-made heating systems. At the same time, the constructions lacked access to running water and energy sources. They also did not meet legal requirements regarding fire safety and sanitary standards. These living conditions certainly fell short of the standards accepted in modern European countries and were unthinkable to the regular people living in big cities such as Wrocław. The encampment was arranged chaotically, with various objects (including items found at landfills) left scattered around the area. A number of complaints from residents of neighboring housing estates spurred the Municipal Police to consider the eviction of the Romani, which was planned for March 2012. The decision was based on the negative opinion of the Provincial Sanitary-Epidemiological Station about the living conditions in the encampment. However, legal consultations showed that the displacement of the citizens of Romania, which is one of the Member States of the European Union, was illegal. Information about the plans that the city authorities had regarding the encampment leaked to the media and gave rise to a major controversy. Over the following months, numerous meetings took place that gathered local and state public officials, representatives of the uniformed services, and migrant specialists. The main problem was to reach a consensus on the scope of jurisdiction and responsibility for the "unwanted" economic immigrants who were, in fact, the citizens of the EU associated country. In 2013, the Municipality of Wrocław finally decided to file a lawsuit for eviction of the Romani. The case aroused a considerable controversy. Numerous acts of negligence and overt discrimination could be observed, e.g., instead of a Romani interpreter, the court appointed a Romanian one. However, the Romani people often no longer speak Romanian due to their long history of emigration [Ferenc, Mandelt 2004, 11-18]. The encampment was finally liquidated in 2018 and the Roma community dispersed. As part of the socio-educational program, Romani families were located in a dozen training apartments rented in various parts of the city by a non-governmental organization, the House of Peace Foundation. The program was commissioned and funded by the $\mathrm{Mu}-$ nicipality of Wrocław. The solution was expected to improve the living 
conditions of the economic immigrants, provide access to education for children of school age, and - in the long term - lead to an increased employability and self-empowerment (in particular, less dependency on the social security system). Families were provided with assistance from social workers. The dislocation of the encampment's residents, however, meant the dispersion of the group and, consequently, upset the relations within the community. It may be thus assumed that the integration with the new sociocultural environment will bring about not only positive outcomes, such as an increased material quality of life (access to hot and cold water, electricity, heating). It may also have negative effects such as the breakdown of existing social bonds within the group and detachment from traditional forms of culture. When it comes to the sense of community or the nature of intra-family relations, it may be expected that they will be significantly influenced by the already mentioned processes of schooling and socialization of Romani children with other students.

Currently, the Roma of Wrocław live in a dozen locations throughout the city and are treated as individual families by the House of Peace Foundation. Such a situation means a significant change in the structure, hierarchy, and social awareness of the community. It requires, among other things, a need for redefining the position of previous community leaders and women, and finding new ways for the community members to interact with the social environment, including e.g., Romani children's attitude towards school. In total, approximately 112 Romani people in 31 families are expected to gain new competencies that would help them develop living independence. They are supposed to learn how to become financially self-sufficient, exercise their rights, and meet their obligations related to being part of the Wrocław community. One of the objectives of the program is also to integrate the Romani customary ways of life (including the ways of earning and managing money) with the cultural and socioeconomic norms in Poland. Key to the process of social adaptation is the ability to maintain a job, the responsibility for the living space, and ensuring children their right to education, which is expected to lead to their emancipation in the future. The process also entails changes in day-to-day practices, such as respecting the rules of the contract with the House of Peace Foundation, timely rent payment, restraining from begging, accepting limitations regarding mobility (including economic migration to other EU countries) and reception of guests (in line with the principles of social coexistence). The families living in the training apartments must also resign from keeping pets and from the "ritual slaughter" of animals. It is crucial to reconcile these 
new principles of life with Romanipen, a set of rules and prohibitions that govern the way of life in Romani communities.

In September 2018, the House of Peace Foundation appointed a research team consisting of employees of the University of Wrocław, PhD students, experts, specialists in the field of cultural and sociological studies of the city, education, and cultural animation. Its members had research experience in the field of urban lifestyle, ethical and aesthetic dimensions of economic inequalities, urban policies, culture as an instrument of social change, and in local and global educational trends.

It was assumed that the results of the empirical research would make it possible to get an insight into the current existential situation of the Romani living in Wrocław, help understand the transformations that have taken place in their community, and explain the dynamics of changes in intra-group relations. The research hypothesis was based on the assumption that not all the solutions offered to the representatives of the community would be accepted by them. An important question was posed: Which of the suggested solutions would be perceived as beneficial and thus encourage the Romani to introduce changes in their daily life, and which would be found oppressive or incomprehensible and thus rejected? The objective was to examine the impact that this process of sociocultural integration had on redefining Romani attitudes and on the elements of their traditional identity. Additionally, an attempt was made to understand how the dispersion of the community and the change in their housing conditions affected the educational aspirations of Romani children. The overarching goal of the interviews and observations gathered was, therefore, to describe the situation of the Romanian Roma after they were moved from the encampment to the training apartments. The research concerned two problem areas. The first focused on the Romani cultural identity, with an emphasis on disintegration processes within the existing community and integration with the new environment (here especially interesting was the potential change in status and ways of functioning of individual families and their members). The second research problem centered around the educational needs and attitudes of adults and children towards school and teaching. In this context, the ability to perceive and appreciate social and individual benefits that education offers to children and youth seemed especially significant. The researchers were also asked to prepare recommendations regarding social policy, social work, cultural animation, and education in the area of identity and integration of the Romanian Roma community in Wrocław. 
An extremely interesting part of the research was the observation of the group's position in the entire urban organism. The city creates opportunities for establishing a dialogue that does not have to necessarily refer to the common good of the residents. It also leaves room for forming an opposition against national, ethnic, racial, or religious concepts. The city may thus be perceived as a laboratory and school of democracy [Barber 2013]. The diversity of lifestyles, perspectives, and beliefs, combined with the sense of community, enhances the emergence of various policies, democratizes decision-making processes, and creates new forms of social relations and negotiated local identities. All these elements contribute to the definition of urban citizenship. There is an increasing number of educational projects that aim at making people (often belonging to excluded groups) more aware and emancipated. Many of them are based on the reciprocal or multidirectional communication models and innovative educational methods that depart from the hierarchical organization of relationship, characteristic of the traditional school system. The purpose of learning and development is to equip individuals and groups with competencies to consciously and independently shape the future of their community, which will eventually improve their quality of life (in terms of economy, ecology, security, infrastructure, etc.). In other words, it is all about creating the opportunity for active participation in democratic processes that aim to ensure a better and more secure future for all the community members, build new types of social relations and a variety of local identities, across any divides.

As part of the program dedicated to the Romani of Wrocław, the community members were offered education at two levels. Firstly, children and youth were (in most cases, for the first time in their lives) made subject to compulsory education. Secondly, all age groups (including children and youth) are being taught practical skills that are required to live in a democratic system governed by the principles of a free market and capitalist economy. The process the Romani undergo may be compared to modernization. For example, the way Romani people conceptualize time is very distinct from what is accepted in modern societies. It becomes evident especially in Romani narratives about the past, for instance, in strategies or methods of presenting time passage dates, periods, days, months, years, etc. Their conceptualization of time can be described as a "stream of life" or the state of embeddedness in everyday existence. The passage of time is not marked by the successive stages of education and career or periods of work and rest (including play). Of course, rites of passage are present in the Romani culture, 
marking the transition from one social role to another, but their location on the timeline is of less importance than in modern European communities. A separate issue is the Romani perception of present time, which is dominated by the sense of temporariness. It is probably connected with the current situation of the Romani families. They do not have any specific scenarios or plans for the future. When asked about their life plans, the Romani can usually only express their willingness to stay in Poland (that is, in Wrocław) or to return to Romania. As part of the program, they are thus taught to be punctual, respect other people's time, plan their work and relax time, and think not only about "hereand-now" but also about the future.

The decision to move the Romanian Roma from barracks to training apartments was expected to improve their living conditions and ensure access to the basic utilities, such as water, gas, and electricity. This significantly raised their living standards, especially in terms of sanitation and hygiene. The community members no longer have to worry about how to provide fuel or construct self-made heating systems. However, the decision appears to have negative impacts as well. For example, the senses of isolation and "not-being-at-home" have been observed in some representatives of the community. Others complain about how little freedom they have to decide on ways they wish to spend time together in their "own" space, especially "outside". The transfer to new locations has also affected the way Romani migrants earn money. Access to the utilities raised the maintenance costs. Prohibition on begging and collecting scrap metal further contributed to the deterioration of the financial situation of the families. The "employment" situation is further complicated by the lack of sufficient language competencies and poor numeracy skills. The change in living conditions and daily duties (including the need to take up a job and send children to school) affected the Romani daily schedule. Community representatives now have more "free time" because they do not have to devote their time to maintaining their informal architecture in good condition. Due to community dispersion, social contacts have weakened. Direct contacts were replaced with phone calls and social media. Ties remain the strongest among family members who occupy the same apartments.

Moving to the training apartments is also associated with more regular school attendance and an increased amount of time Romani children spend there, which means closer and more direct contacts with Polish children. Previously, Romani children had access only to individual forms of education offered by NGOs. Compulsory education and related social benefits that were offered by state institutions and non- 
governmental organizations, combined with lifestyle changes, led to a situation where school and integration with peers started to play an increasingly important role in the lives of Romani children.

As I have already mentioned, one of the researchers' tasks in the project was to create recommendations regarding social policy, social work, cultural animation, and education in the area of identity and integration of the Romanian Roma community in Wrocław. This means that the researchers commissioned by the Municipality of Wrocław were expected to propose solutions that could be implemented to improve the situation of the Romani community. In this way, the project goes beyond what can be referred to as basic research, that is, a systematic investigation to establish facts and create new knowledge about the world. It may be classified as applied research, that is, a methodology used to create knowledge that may serve as a practical solution to a specific problem. At the same time, it is deeply rooted in local politics the actions taken by the city administration. The Romani encampment has been an object of heated discussions between, i.a., various non-profit organizations focused on improving living conditions and creating education opportunities for the Roma and the representatives of the regional and national authorities. Local and national media were also involved. The parties to the dispute were, of course, also the city residents who presented their arguments both in press, radio and TV interviews and on social media. Inevitably thus, the research team representing the academia also became involved in this social and political conflict. All this leads to many fundamental questions regarding the role of science in diagnosing the existing reality and recognizing the voices of people who used to be excluded from the public discourse. Furthermore, it creates questions concerning liberal democracy, or, more broadly speaking, modernity projects based on the concepts of the Enlightenment. An important component of this reflection is the issue of ethnicity and cultural identity as well as issues related to education and social progress. An important aspect is also the already mentioned education, both formal and informal, with its emancipatory potential. Education may in the long term become a driver for social transformation regarding political, economic, symbolic, and axiological dimensions.

The nature of the current study requires an interdisciplinary approach. On the one hand, it centers around the issue of cultural differences and relativism; on the other, it constitutes a political and philosophical reflection on democracy (both liberal and non-liberal). It thus inevitably touches upon the concepts of coercion and freedom considered both at 
the community and the individual level. It is also extremely important to consider the extent to which the process of adaptation and modernization of communities such as the Romani can take place under the legal system of liberal democracies. Equally important is also to understand the scope of responsibilities of modern states and international organizations towards the citizens referred to as "excluded". Here I would like to come back to the issue of tension between the policies and procedures introduced by European states to make the Romani fit into modern legal and economic frameworks and the attempt to preserve the Roma's cultural identity. The best suggestion to avoid past mistakes while aiming at increasing the productivity of the Romani and other marginalized groups ${ }^{1}$ is the implementation of "radical democracy", a concept created by Chantal Mouffe and Ernesto Laclau [1985]. One of the basic assumptions behind this ideology is "the more pluralism, the more democracy" [Koczanowicz 2005, 16]. The greater the inclusion, the greater the diversity of voices. The greater the diversity of voices, the more difficult it is to reach the mythical consensus that we all know from liberal democracies, and the more room is created for different ways of living. In this way, the idea of diversity may be realized, the foundations on which democracy is built can get stronger, and the threat of populism or non-liberalism may be reduced.

\section{REFERENCES}

Barber 2013 - Barber, B. If Mayors Ruled the World. New Haven; London: Yale University Press. 2013.

Ferenc, Mandelt 2013 - Mandelt, M., E Ferenc, A. Systemic exclusion and integration/situation of Romanian Roma living in Wrocław. Wrocław: [s.n.]. 2013. (In Polish).

Koczanowicz 2005 - Koczanowicz, L. Antagonism, agonism and radical democracy. Chantal Mouffe policy concept. In C. Mouffe, The Democratic Paradox. Translated by W. Jach et al. Wrocław: [s.n.]. 2005. (In Polish).

Kwadrans 2013 - Kwadrans, Ł. Roma. Close-Unknown. One of many. RomaRising. In J. Balkowski (Ed.), Heroes of the social campaign One of many in the lens of Chad Evans Wyatt. Wrocław: [s.n.]. 2013. (In Polish).

\footnotetext{
${ }^{1}$ This article concerns the Romanian Roma community in Wrocław, however, this does not mean that the issues discussed here apply only to this group. Similar questions can be asked in the context of other groups that are subject to marginalization, based on race, gender, religion, economic status, origin, etc.
} 
Laclau, Mouffe 1985 - Laclau, E., \& Mouffe, C. Hegemony and Socialist Strategy. Towards a Radical Democratic Politics. London; New York: Verso. 1985.

Prokop, Mach 2016 - Prokop, J., \& Mach, E. Romanies in Poland and in the Czech Republic. Social and Educational Aspects. Cracow: 'Scriptum' Publishing House. 2016. (In Polish).

Szczepaniak 2015 - Szczepaniak, A. Introduction. Romanian Roma in Poland. In P. Witkowski, \& A. Szczepaniak (Eds.), Guide to working with the community. Wrocław: [s.n.]. 2015. (In Polish).

Материал поступил в редакциию 03.08.2019 Материал поступил в редакцุию после рецензирования 24.05.2020 